TEACHER EDUCATION: CURRENT TRENDS AND CHALLENGES

\title{
IN TEACHING AND RESEARCH
}

\section{MANJU S. TONK, HEMANT POONIA*, REKHA, NISHA RANI \& KAUTILYA CHAUDHARY}

Chaudhary Charan Singh Haryana Agricultural University, Hisar, Haryana, India

\begin{abstract}
A teacher education is a program which includes some specific pedagogical issues. Teacher education program generates the solution regarding how good teaching is performed and how teaching work and practicals are managed. Teacher's education programs are very closely related to theory and its practicals. A teacher can become a good teacher by working continuously with learned and experienced teachers in a traditional classroom or virtual classroom on internet and enhances the knowledge. Teachers' proficiency and competence can be enhanced by facing current challenges in the educational system. Now days, the education of teachers should not be limited with only contents of books. It should be broadened in different new areas, innovations, techniques etc. The main aim of this article is to indicate main changes in teacher's educational system in India and also give an overall view of current trends, innovations, new techniques and reforms in educational system. In educational system, it is need to discuss the current needs of teacher's education and teacher education program including new innovative ideas and various practices. The teacher education program should be shaped and altered in such a way that a teacher could be enabled to face the new challenges, current trends and problems in the field of education and can help in national development.
\end{abstract}

KEYWORDS: Teacher Education, Current Trends, New Challenges and Educational System

Received: Mar 23, 2019; Accepted: Apr 13, 2019; Published: Jun 05, 2019; Paper Id.: IJESRAUG20193

\section{INTRODUCTION}

In the present educational system a teacher's role has changed from teacher to a Mentor and felicitator. Mentoring and guidance plays a key role in the progress of teacher education and educational system. Traditionally, we are seeing the slogan written on the walls of educational institutes "Asto ma sadgamay tamso ma jyotirgamay". Academic institutions should function like a torch bearer to guide the students and lead the society from the darkness of ignorance to the light of knowledge. This knowledge brings actual transformation in the academic growth of the student, society and the country as whole. To light this torch of knowledge teachers work both as charge and charger. At any stage, an educator is responsible for implementation of the educational system and process. Thus, it is of vital importance to invest in development and trainings of teachers.

\section{MEANING AND ROLE OF TEACHER EDUCATION}

The learning achievements basically depend on knowledge, competence of a teacher to clear the concept of majority of the students, ways of expression, effective delivering of contents. Thus, the role of the teacher is to teach the students in a manner that it can enhance the theoretical and practical knowledge of the students.

Teacher education means to train the graduate and post graduate students to become teacher through special education and training. The basic idea is that we can educate a person to become a teacher. This rejects the idea that 
teachers are born.

The need of preparing the teachers defines the role and concept of teacher education. An education program developed for education, training and research of persons to mentor the students from pre-primary to higher education level.

It can be said that all educational activities whether it is formal or informal that help to prepare and enable a person to take the responsibilities of teaching students efficiently and in a planned manner. The teacher education empowers the teaching profession and develops the attitude to face the upcoming challenges.

According to Goods Dictionary of Education Teacher education means all formal and non-formal educational activities and teaching and research experiences that help to enable a person to take the responsibilities of a member of the educational profession or to discharge his responsibilities more effectively. The development of teaching skill, competency and proficiency that are strongly connected to the teacher education, would strengthen the teacher competency and proficiency to meet out the requirements of the profession and face the challenges therein. Teacher education enhances teaching \& research skills, strong pedagogical theory and professional skills.

\section{Nature and Need of Teacher Education}

The theory behind the teacher education is that teachers are not born but they are shaped to be a teacher. Commutation is a way of teaching which can be oral, practical, hands on and through technology. Hence, it becomes both science and an art. To impart knowledge with different modes of interaction, the teacher has to acquire all skills that one called the tricks of the trade. Education for teacher's can be both broad and comprehensive. In order to prepare teachers who are capable of facing the challenges of the modern dynamic society. Teacher education needs inclusion of current and advance information and developments.

\section{Teaching Skills}

Teaching skills include strengthening of recent communication techniques and strategies that would support the educators to plan and impart lessons, provide appropriate reinforcement and conduct effective assessment. It also involves effective teaching and learning skills, communication skills and preparation of instructional materials.

Teaching Pedagogy involves the sociological, psychological and philosophical aspects that would empower the teachers to have a strong basis for better communication in the classroom.

Professionalism involves the strategies, techniques and approaches that would help teachers to grow in the profession and also work towards the growth of the profession. It involves advisory skills, soft skills, computer skills, interpersonal skills, information generating and compiling management skills and above all lifelong learning\& teaching skills.

Thus, for promoting the holistic development of teaching skills and to enhance attitude and skills in the teacher's pedagogical theory and professional skills remain the key factors. This can be possible by focusing on preparation of a teacher not only through training but building a program including holistic combination of teacher and learning strategies with recent methods.

To make good decisions, teachers must know the different ways of expression of learning in the context of 
development, learning differences, language and cultural influences, and individual temperaments.

\section{Emerging Trends in Teaching}

National Council for Teacher Education (NCTE) is a non-statutory body which is set up to improve teacher education. Use of computer and internet in this field has brought a sea change in the procedures and patterns of information and communication technology. Education today is more than teaching and learning with an emphasis on technology. The educational technology has progressed from classroom lectures and seminars to virtual classrooms. The virtual classroom means there are no limits on learning or where they can learn. But people with an access to information and knowledge will have the best opportunities to improve their knowledge and skills.

\section{E-Learning}

Electronic learning means learning through computers \& internet. Computers and information technology includes various types of tools and media that deliver information through audio and video lectures, animation films etc. It also includes satellite, TV, web-based learning and the web-technology. E-Learning enables a teacher to impart knowledge to the student sitting in different geographical locations. ICT has bridge this gap between educators and pupils. Learning through multimedia, computer based instructions, computer based learning, computer aided instruction etc. are the results of advancement in information and communication technology.

Learning programmers and events which are planned, managed and delivered through software applications are most, useful for the corporate training departments of a big organization. It also facilitates online access to learning contents and administration of the organization. Technical competence and creativity enables educators and managers to compile most important but complex contents and material into comprehensive but easy to understand the material.

Information and communication technology has opened the doors of understanding global trends in education. Current information can be received, retrieved and send in any part sitting in any corner of the country or abroad through internet. Educational institutes can update with recent needs of teaching and learning both in technology and reading material. Teacher, administration and students can be connected through this network across the institution, outside the institution. Web supported class rooms have become very popular.

This ICT set up has enhanced the strength and responsibility of educational institutes to have and produce such educators who can train the students using this technology and to make the students, savvy also. Internet has given a new meaning to distance education as online courses and reading material can be easily available. But, all these technologies can be a boon if teachers and learners are professional by nature and habit in their field of work.

\section{Research Skill}

Educational research is to innovate new methods and develop new knowledge which can be applied to the up gradation of educational practices. Similarly, research in teaching is required to develop and test the outcomes of the research. The findings of the research should contribute to enhance educational knowledge and to demonstrate reviews of related research finding to literature. It is difficult to judge whether the adoption of research findings will desired impact on the practice of education. The policy makers in education the research outcomes are generally considered as source of information which is used in framing particular policy. The research skills are also used to justify unpopular decisions, minimising funds or to counter and dismiss the previous research findings which are unjustified and contradictory their 
opinion.

\section{Nature and Need of Research Skills}

The main aim of research in teacher education is to study the existing educational phenomenon and to bring required changes. This facilitates the teachers and research to explain the concept, study the control and to make recommendations regarding the dynamics of a given phenomenon. This information gathered to this study will lead to research and develop new methods of training, their affect on the performance of teacher training in teaching practice. The without such research the teacher educators and policy makers will not be able to make precise conclusions about the effectiveness of the teacher training. In the modern era, the changes in society are very fast. Teacher education and its practitioners are also changing continuously. It may be possible that the societal changes are making an impact on teaching, learning and education system as whole. Hence as a result education is changing both in terms of contents, teaching learning methods and practices.

There is a democratic angle to the research in education. Our education is rigid and our education is scripted. It is often scripted by persons and professionals who are much distant from the field and practice of education in schools and colleges. Who will solve problems of quality and those emerging out of daily practice? Individual teachers need to tackle the problem in the classroom. Because, problems will be solved only where they exist. Individual teachers doing research to solve their practical problems are a requirement of democratizing the education system of this nation. Who suffers most from low quality teaching? It is depriving children whom the low quality of education and schooling affect most. Teaching and teachers matter most especially for deprived students.

Research in teaching enables the educators to develop teaching and learning environments, instructional material and teaching practices. The basic understanding of subject and teaching methods among fresh teachers and teacher educators remains average in starting of their teaching career. The concepts and strategies of teaching and learning practices improve with the help of with continued research and feedback strategies. However, it is not always true that a teaching model which an outcome model will always be successful but are followed by successors. The model that has not been a successful teaching tool can be modified again with the required changes and retested

Teacher educators are most reflexively focusing their attention on secondary schooling. Who will inform primary sector. What are the special problems of learning Hindi? Who will research and find solutions to these problems other than teachers and teacher educators in North India? Don't we have our own issues of teaching and learning Hindi? Is Secondary education more important than primary education for human development? What is our immediate goal? Then why we have more research on secondary education than primary?

Problems abound in schools. We must research because we have problem aplenty in our schools. How shall we evaluate the areas - Personality, punctuality, industriousness and courtesy? For that matter how shall we judge a project, seminar, drawing, handwriting? Why should we have separate methods of teaching Hindi, Sanskrit, and Arabic and Urdu, or English? Why methodology of teaching these languages is considered specialization? Are there differences in methods and techniques employed in teaching these languages? How much of teaching practice we need to have? At what interval? Does teaching practice add to students teaching competence? To what extent?

If teachers and teacher educators and other educational practitioners don't convey the policy makers on important issues in education, who else will do? If every teacher and teacher educator of us feel that I am not responsible, who else 
are responsible?

Research in Education is reflective learning from teaching. We have lakhs of educational practitioners. Why is it that at least some of them sit down and pen what they have learned from decades of educational career? Is it that they did not have any experience to share? Or is it that we have not learned anything from experience? Is it that we haven't time to reflect on and integrate the simple principles.

Research helps in changing vision and manner of practice. It is documented to help the colleagues for gemmating insight in field of teacher education. Continuous research in this area helps in connecting new findings with the contents for better learning outcomes. Thus this fulfils the need of advancement in the area and to adjust one's teaching in accordance with new and more effective possibilities.

Education practice is the area of research in teaching education. We have many practices in teaching education such as teaching practice \&classroom practice. We have to develop teachers and teacher educators with practical wisdom, current technologies, technical knowledge and critical reflection.

But, there are also well designed interaction programs for promoting and capacity building. Simultaneously, teaching education as a learning environment can be seen for all people involved in this interaction process. Outcomes cannot be improved only extending the time spent by learner teachers in the classroom.

We have to find ways to enhance the content and structure of programmes related to teacher education including research activities to inform the design. The use of research-based skills and knowledge for improving school performance and student outcomes. What is missing among the teachers and teacher educators most is capacity for critical reflection, i. e. the type of deeper insight and understanding that comes from interrogating one's practice based on the wider research evidence.

Research is required to manage hierarchical triads in teaching education. There is no existent organizational structure for teaching education to support researchers.

The main constraints and challenges in teaching and research in Teacher Education are:

- Lacking in clarity of objectives

- Shortage of trained and qualified Personnel

- Lacking in motivational environment

- Inadequacy of facilities and resources

- Budgeting problem

\section{CONCLUSIONS}

Thus, it can be summarised that teachers should develop lesson plans, e-lectures, assignments, examine and evaluate student's performance and give a feedback in terms of sharing their strength and weaknesses. According by the lectures must be planned, again observe and analysis outcomes and further modify plans to meet the requirements. Thus, continuous efforts must go on to improve innovation and research in teacher education. Teacher education needs documentation of research and its reflection in terms of implementation through course curriculum, trainings and other 
programs.

The teacher can conduct research on their own subject. To meet the objectives, they can collaborate within and outside the institution. The outcomes of the research must be shared by documentation, including in lesson plans and practical demonstration. The impact of the particular intervention must be assessed and then final recommendation can shared for adoption by other stakeholder's also. The different system exists in different location and work independently. Efforts should be made to find the ways of combining their research in teaching can be done together with teaching. Teachers and teacher education must research jointly to generate new ways of effective teaching for better and fruitful learning during classroom teaching.

\section{REFERENCES}

1. Rathod, Jgdish B., Ph. D.,(2016) Emerging Trends in Teacher Education, International Journal of Educational Research Studies, JAN-FEB, VOL-I, ISSUE-V,355-359.

2. Dhodi, N. (2011). Development and Implementation of a Program for Enhancing Info-Savvy Skills in Student Teachers, a Ph. D. Thesis, The M. S. University of Baroda.

3. Dutta A. (2009). Designing, DevelopingandImplementinganEducationalProgramforEnhancingEmotionalMaturityofStudentTeachers, a Ph. D. Thesis, M. S. University of Baroda.

4. Barai, B. Professional Experiences Of Teacher Trainer With K-Yan During Primary Teacher Training Programme.

5. Goel D. R., Goel C., Madhavi, R. L.(2010). Abstracts of Research Studies conducted by Teacher Education Institutions, Vol. I, II and III, 2007, 2008, and 2010 www.educationinindia.net

6. Rao, G. K. (2009). A Study of Human Resource Development Climate in the DIETs of Rajasthan, a Ph. D. Thesis, The M. S. University of Baroda.

7. Helaiya, S. (2009). Development and Implementation of a Life Skills Program for Student-Teachers, a Ph. D. Thesis, The M. S. University of Baroda.

8. KyoungHye, L. K., SukJa, K., \& HeeJu, H. (2016). An Analysis of Art Activities for Arts Convergence Education: Focused on the Age 5 Nuri-Curriculum Teacher's Guidebooks. International Journal of Educational Science and Research (IJESR), 6(3).

9. Madhavi, R. L.(2009). Relative Predictivity of some Selected Variables for Admission into M. Ed. Programme, a Ph. D. Thesis, The M. S. University of Baroda.

10. NCTE(2009). National Curriculum Framework for Teacher Education: Towards Preparing Professional and Humane Teacher, NCTE, New Delhi.

11. PP, S. (2017). Job Satisfaction of Women Teachers With Special Reference to Malappuram District. International Journal of Human Resources Management (IJHRM), 6(6), 1-8.

12. Sansanwal D. N.(2008). VI Survey of Educational Research, DAVV, 2007-08, www.dauniv.ac.in.

13. Siddiqui M. A., Sharma A. K., \& Arora G. L. Eds(2009). Teacher Education: Reflections Towards Policy Formulation, NCTE, New Delhi.

14. http://www.e-learning.com

15. http://www.writingenter.uncedu 